\title{
KONSEP BERITA DALAM AL-QUR'AN (IMPLIKASINYA DALAM SISTEM PEMBERITAAN DI MEDIA SOSIAL)
}

\author{
Oleh : Iftitah Jafar \\ Dosen Jurusan Jurnalistik Fakultas Dakwah dan Komunikasi UIN \\ Alauddin Makassar \\ Email : iftitahjafar@yahoo.co.id
}

\begin{abstract}
This paper aims at revealing the concept of news in the Qur'an. Even though the Qur'an is not the book of science it contains some scientific clue includes journalistic. One of journalistic aspects is news. The Qur'an provides some basic concept of news which covers key terms of news, its classification, and its implication in the news release. Qur'anic concept of news refers to these key words namely: 1. Al-naba', al-hadith, and al-'ifk. News can be classified among others, in four classifications: 1 . News of ancient people, the prophets and their communities, 2. News of scientific contents of the Qur'an, and 3. News of the unseen. Social media plays some important role includes: 1 . As a medium of friendship, 2. As a medium as ideas sharing, 3. As a medium of business, and 4. As a medium of $\mathrm{Da}^{6}$ wa. The implication of social media covers: 1 . News should have a clear source, 2. News should be true, and 3. News should be met with the fact.
\end{abstract}

\section{Pendahuluan}

\section{Keywords :}

Berita, Implikasi, Pemberitaan

Para pakar dan pengamat media menilai bahwa abad ke-21 merupakan abad teknologi dan informasi, dimana umat manusia memasuki era "millennium informasi. Era ini ditandai dengan informasi yang disebarluaskan melalui media massa akan secara signifikan menentukan arah perkembangan masyarakat. Terdapat kecenderungan pada sebagian manusia khususnya sebagian umat Islam, dalam era informasi dewasa ini dihadapkan pada perubahan nilai. Saat ini seolah-olah apa yang diberitakan media massa dianggap benar. Realitas sosial telah dipersempit maknanya menjadi "realitas media" seperti apa yang disiarkan media massa. Kecenderungan penyempitan makna ini selain menjadi kesadaran bersama, juga menambah besar tanggungjawab social media massa. ${ }^{1}$

Dalam lima tahun terakhir agaknya terjadi pergeseran penggunaan media sosial. Kondisi ini diperparah lagi di saat menjelang pemilihan umum, terutama Pilkada serentak, seperti yang terjadi akhir 2016 dan awal 2017. Media ini menjadi ajang politik yang digunakan untuk saling menyerang. Akibatnya berita hoax banyak mewarnai postingan di media ini. Selain itu media ini disalahgunakan sebagai instrument untuk membully, memfitnah, memerovokasi yang dapat merusak citra seseorang atau sebuah lembaga. Dengan kondisi ini, agaknya etika religius,

1 https://hshidayat.wordpress.com/2013/12/11/tabayyun-terhadap-informasi-bagian-terpenting-tanggungiawabmedia-islam/ (09 Februari 2017) 
khususnya yang diadopsi dari kitab suci menjadi sesuatu yang niscaya dan dibutuhkan, agar umat mendapatkan pencerahan di tengah arus perkembangan teknologi informasi dengan berbagai dampaknya.

Al-Qur'an sebagai kitab suci dan pedoman hidup bagi umat Islam, meskipun bukan kitab ilmu pengetahuan ia mengandung isyarat-isyarat ilmiah. Salah satu isyarat ilmiah yang dapat dipahami dalam dari ayat-ayat Al-Qur'an adalah memberi landasan pokok bagi ilmu pengetahuan tertentu termasuk jurnalistik. Peran-peran kewartawanan sesungguhnya telah ditunjukkan dalam proses turunnya kitab suci, khususnya Al-Qur'an. Malaikat Jibril membawa berita langit ke dunia dan menyampaikan kepada manusia melalui Nabi Muhammad saw. dalam QS. al-Nahl (16): 102, Allah berfirman: "Katakanlah Ruhul kudus (Jibril) menurunkan AlQur'an dari Tuhanmu dengan kebenaran." Dalam kajian hermeneutika posisi jibril ini diperankan oleh Hermes, dewa dalam mitologi Yunani yang bertugas menerima pesan-pesan langit dari Maha Dewa untuk selanjutnya dijelaskan kepada manusia. ${ }^{2}$ Manusia sendiri tidak bisa secara langsung memahami pesan-pesan langit sehingga memerlukan mediator. Jibril, dari sisi ini memainkan peran mediator antara Tuhan dan manusia karena kapabilitas dan kapasitasnya yang bisa berada pada setidaknya dua dimensi; dimensi malakut dan dimensi insaniyat. Dalam Ilmu Komunikasi, Malaikat Jibril berfungsi sebagai saluran atau channel pesan-pesan ketuhanan yang disampaikan kepada manusia sebagai penerima pesan (recipient) yang diwakilkan pada Nabi Muhammad saw. Sebagai channel Malaikat Jibril tidak menambah atau mengurangi pesan-pesan ilahi tadi, karena tugasnya hanya menyampaikan.

Beberapa pertimbangan di balik penunjukan Jibril sebagai pembawa berita dari Tuhan. Ia merupakan makhluk Tuhan yang istimewa. Malaikat merupakan makhluk Tuhan yang paling taat dan tidak pernah durhaka kepada Tuhan. Dalam QS. al-Tahrim (66): 7, Allah swt. berfirman: "6. Hai orang-orang yang beriman, peliharalah dirimu dan keluargamu dari api neraka yang bahan bakarnya adalah manusia dan batu; penjaganya malaikat-malaikat yang kasar, keras, dan tidak mendurhakai Allah terhadap apa yang diperintahkan-Nya kepada mereka dan selalu mengerjakan apa yang diperintahkan. Ia tidak berkata-kata selain diizinkan oleh Allah dan ia senantiasa berkata benar (QS. al-Naba' (78): 38). Ia diberi julukan sebagai rûh al-amîn, (QS. al-Syu'ara' (26): 193), yakni jiwa yang terpercaya, dan rûh al-qudus, (QS. al-Nahl (16): 102), yaitu jiwa yang suci. Karena kedua kapasitas inilah antara lain mengapa Jibril dipercaya menyalin AlQur'an di Lauh Mahfudh. Lawh Mahfudh sendiri tidak bisa diakses kecuali mereka yang suci atau disucikan Tuhan. Dalam QS. al-Waqi'ah (56): 79, Allah berfirman, "Tidak ada yang menyentuhnya selain hamba-hamba yang disucikan". ${ }^{3}$

Nabi Muhammad saw. selain berperan recipient beliau juga memainkan peran sebagai pengirim pesan (sender) karena beliau juga menyampaikan pesan-pesan ketuhanan kepada umatnya. Pesan atau berita tersebut adalah ayat-ayat Al-Qur'an yang nantinya akan berfungsi sebagai sebagai pedoman hidup bagi mereka (QS. al-Baqarah (2):185). Al-Qur'an akan

\footnotetext{
${ }^{2}$ Komaruddin Hidayat, Memahami Bahasa Agama (Jakarta: Paramadina, 1996), h. 12.

${ }^{3}$ Penulis memahami "mereka yang disucikan " dalam ayat ini dengan malaikat, mereka memang makhluk yang disucikan sehingga mendapat privilege untuk mendapatkan akses Lawh Mahfudh. Konteks ayat tersebut seperti disebutkan dalam dua ayat sebelumnya adalah Al-Qur'an di Lawh Mahfudh. Pendapat lain adalah orangorang yang beriman, orang-orang kafir tidak boleh menyentuh Al-Qur'an. Sebagai tambahan, sebagian umat Islam memahami ayat tersebut dengan orang-orang yang sudah berwudhu'. Jadi hanya orang yang sudah berwudhu' yang bisa menyentuh dan membaca Al-Qur'an. Pendapat lainnya adalah orang kafir boleh saja menyentuh AlQur'an. Mereka tidak boleh menyentuh dalam artian mengutak atik substansi Al-Qur'an.
} 
meneguhkan hati orang-orang yang telah beriman dan menjadi petunjuk serta kabar gembira bagi orang yang berserah diri kepada Allah (QS. al-Nahl (16): 102).

Konsep berita dalam Al-Qur'an mutlak diperlukan. Konsep ini akan menjadi pedoman dan bimbingan bagi umat Islam dalam menghadapi berita-berita yang beredar di tengah-tengah masyarakat. Konsep ini diperlukan baik pada tataran teoretis maupun praktis. Secara teoretis konsep berita dalam Al-Qur'an akan memberkan kontribusi dalam pengembangan kajian jurnalisme, terutama jurnalisme prophetic. Secara praktis konsep berita dalam Al-Qur'an akan menjadi panduan bagi umat Islam mencermati dan berdialog dengan berita yang menerpa mereka. Makalah ini mencoba mengungkapkan konsep dasar berita dalam Al-Qur'an. Pembahasan akan mengikuti sistimatika sebagai berikut: pendahuluan, konsep dasar berita, klasifikasi berita, Rasul sebagai pembawa berita dan implikasi berita dalam system pemberitaan di media sosial.

\section{Pembahasan}

\section{A. Konsep Dasar Berita dalam Al-Qur'an}

Berita menempati posisi sentral dalam Al-Qur'an. Mengenai berita Al-Qur'an menawarkan beberapa konsep dasar atau terma kunci: al-naba', al-khabar, al-hadîts dan al-'ifk.

\section{Al-Naba'}

Kata al-naba' berasal dari kata naba'a seakar kata dengan al-anba' (menginvestigasi), al-nabi'u (tempat yang lebih tinggi), dan al-nabiy (pembawa berita=nabi). Kata al-naba' dalam Al-Qur'an disebutkan sebanyak 29 kali; 17 kali dalam bentuk tunggal dan 12 kali dalam bentuk jamak. Penggunaan term naba' dalam Al-Qur'an pada umumnya merujuk pada pemberitaan yang sudah dijamin kebenarannya, atau sangat penting untuk diketahui, meskipun manusia belum bisa membuktikannya secara empirik karena keterbatasan ilmunya. Termasuk dalam kategori ini adalah berita ghaib, khususnya tentang hari kebangkitan. Selain itu juga terdapat penggunaan kata naba' dalam arti pemberitaan yang disampaikan Tuhan yang dapat diketahui manusia karena kemampuan ilmu yang dimilikinya. Berita-berita tentang umat terdahulu yang disampaikan Allah kepada Nabi Muhammad saw. termasuk dalam bagian ini. Berita-berita seperti ini antara lain disebutkan dalam QS. Hud (11): 100, 120, QS. Thaha (20): 99, dan QS. al-A'raf (7): 101.4

Al-naba' (berita yang penting), hanya digunakan bila ada peristiwa yang sangat penting dan besar, berbeda dengan kata khabar, yang pada umumnya digunakan juga pada berita-berita sepele. Sementara, ulama mengatakan berita baru dinamai naba' apabila mengandung manfaat yang besar dalam pemberitaannya, adanya kepastian atau paling tidak dugaan besar tentang kebenarannya. Penyifatan al-naba' dengan kata al- 'azhim (besar, agung) menunjukkan bahwa berita tersebut bukanlah hal biasa tetapi luar biasa. Bukan hanya pada peristiwanya tetapi juga pada kejelasan dan buktibuktinya, sehingga mestinya ia tidak dipertanyakan lagi. ${ }^{5}$

${ }^{4}$ Lihat M. Galib Mattola, “naba”" dalam Sahabuddin et al (ed.), Ensiklopedia Al-Qur'an: Kajian Kosakata, Vol. 2 (Jakarta: Lentera Hati, 2007),h. 675.

${ }^{5} \mathrm{M}$. Quraish Shihab, Tafsir Al-Mishbah:Pesan, Kesan dan Keserasian Al-Qur'an, Vol 15 (Jakarta: Lentera Hati,2002), h. 6. 
Satu-satunya kata al-naba' yang digunakan dengan pelaku orang fasik disebutkan dalam Q.S. al-Hujurat (49): 6. Kata al-naba' dalam ayat ini tidak memberi pengertian bahwa berita yang disampaikan benar, tetapi lebih menekankan agar umat Islam lebih berhati-hati terhadap pemberitaan yang disampaikan orang fasik. Kasus yang direkam dalam ayat ini adalah pemberitaan yang berkaitan dengan kemasyarakatan. Karena demikian pentingnya sehingga kalau tidak ditanggapi dengan penuh kehati-hatian dapat menimbulkan instabilitas dan disharmoni, bahkan dapat menyebabkan kekacauan. Perintah tabayyun dalam ayat ini dimaksudkan sebagai upaya menjaga kemungkinan timbulnya dampak negatif sebagai akibat tidak selektif dalam menerima berita. ${ }^{6}$

\section{Al-Khabar}

Secara etimologi kata khabar terdiri dari huruf $k h a$, $b a$, ra yang mengandung dua makna yakni ilmu dan menunjuk kepada yang halus dan lembut. Secara gramatikal, khabar merupakan bentuk mashdar (kata jadian atau bentukan), yang bermakna "kabar dan berita". ${ }^{7}$ Secara epistemologi, khabar adalah tentang laporan yang biasanya belum lama terjadi, namun tidak dikategorikan berita penting dan besar. Khabar bisa pula dimaknai sebuah berita biasa yang datang belum tentu memiliki nilai kebenaran. Beritanya tersebar terkadang lebih hebat dari kenyataan yang sebenarnya. ${ }^{8}$

Kata khabar antara lain disebutkan dalam dalam kasus penerimaan wahyu dan pelantikan Nabi Musa as. menjadi Rasul Allah yang disebutkan dalam QS. alNaml/27: 7, dan QS. al-Qashash/28: 29. Dalam QS. al-Naml/27: 7, disebutkan: "(Ingatlah) ketika Musa berkata kepada kelurganya: Sesungguhnya aku melihat api. Aku kelak akan membawa kepadamu khabar daripadanya, atau aku membawa kepadamu suluh api supaya kamu dapat berdiang." Ayat yang semakna disebutkan.

\section{Al-Hadits}

Hadis berasal dari bahasa Arab, hadasa, yahdusu, hadisan, berarti al-jadid, yang baru. Merupakan lawan kata al-qadim (yang lama). Jadi hadis adalah "sesuatu yang baru" atau berita. Orang yang baru masuk Islam misalnya, dapat disebut rajul hadas al-sinn, orang dalam "berita". Kata hadits dalam makna berita antara lain disebutkan dalam QS. al-A'raf/7: 185,'Dan apakah kalian tidak memperhatikan kerajaan langit dan bumi dan segala sesuatu yang diciptakan Allah, dan kemungkinan telah dekatnya kebinasaan mereka?. Maka kepada berita manakah lagi mereka akan beriman selain kepada Al-Qur'an itu?.

Hadis merupakan sinonim khabar atau berita dalam arti umum. Masa-masa awalnya hadis tidak saja berita dari Rasulullah saw., tetapi juga berita-berita lain, termasuk Al-Qur'an. Ini terlihat antara lain dalam ucapan Ibn Mas'ud. "Sebaik-baik hadis adalah kitab Allah dan sebaik-baik petunjuk adalah Muhammad" Hadis secara bahasa berarti percakapan atau perkataan. Dalam terminologi Islam perkataan yang dimaksudkan adalah perkataan dari Nabi Muhammad saw. Sering kali kata ini

\footnotetext{
6 Lihat M. Galib Mattola, “Naba”" h. 676.

${ }^{7} \mathrm{Abu}$ Al-Husain Ahmad ibn Faris ibn Zakariyya, Mu'jam Maqayis fi al-Lughah (Cet. I; (Beirut: Dar al-Fikr, 1994), h. 339.

${ }^{8}$ Ilham Badu, Berita Terorisme Dalam Perspektif Media Cetak; Studi Kaus Koran Republika dan Koran Kompas, h.16-17.
} 
mengalami perluasan makna sehingga disinonimkan dengan sunnah sehingga berarti segala perkataan (sabda), perbuatan, ketetapan maupun persetujuan dari Nabi Muhammad saw. yang dijadikan ketetapan atau pun hukum dalam agama. Hadis sebagai sumber hukum dalam agama memiliki kedudukan kedua pada tingkatan sumber hukum di bawah Al-Qur'an. Arti umum hadis dalam perkembangannya terjadi penyempitan sehingga akhinya kalau dikatakan hadis maka tertuju pada apa yang dinisbatkan kepada Rasulullah saw. ${ }^{9}$

\section{Al-'Ifk}

Kata al-'ifk disebutkan dalam berbagai bentuknya disebutkan sebanyak 22 kali dalam Al-Qur'an. Kata al-'ifk digunakan dalam Al-Qur'an untuk arti sebagai berikut: 1. Perkataan dusta, yakni perkataan yang tidak sesuai dengan kenyataan. Ia disebutkan dalam kasus isteri Rasulullah saw. Aisyah ra. (QS. al-Nur/24: 11). 2. Kehancuran suatu negeri karena penduduknya tidak membenarkan ayat-ayat Allah, misalnya QS. al-Tawbah (9): 70. 3. Dipalingkan dari kebenaran karena mereka selalu berdusta, seperti QS. al-Ankabut (29): 61.

Kata 'ifk diartikan dengan “perkataan bohong” digunakan Al-Qur'an untuk melukiskan : a. Kebohongan orang kafir tentang sembahan mereka yang dapat memberi syafaat bagi yang menyembahnya (QS. al-Ankabut (29): 17, b. Kebohongan orang kafir yang mengatakan bahwa Allah beranak (QS. al-Shaffat (37): 151, c. Kebohongan orang kafir yang mengatakan bahwa Al-Qur'an itu tidak memberi petunjuk bagi manusia (QS. al-Ahqaf (46): 11), d. Kebohongan orang munafik yang mengatakan bahwa sahabat Rasulullah berbuat skandal dengan isteri Rasul (QS. alNur (24): 11-12) $)^{10}$

\section{B. Klasifikasi Berita}

Berbagai varian klasifikasi berita ditawarkan para ahli. Varian klasifikasi ini tentunya terkait erat dengan perspektif suatu kajian. Dalam perspektif dalam Al-Qur'an berita dapat diklasifikasi sebagai berikut.

\section{Berita umat-umat terdahulu}

Al-Qur'an kaya dengan berbagai berita tentang para Nabi dan umat terdahulu. Berita-berita tersebut terjamin kebenarannya karena didasarkan pada kisah yang ril. Pandangan ini setidaknya ditopang oleh tiga ayat: QS. Ali Imran (3): 62, QS. al-Kahfi (18): 13, dan QS. al-Qashash (28): 99. Berdasarkan ayat-ayat ini dapat digarisbawahi bahwa kisah-kisah dalam Al-Qur'an semuanya benar-benar terjadi, bukan fiksi, khayalan, apalagi dongeng. Hal ini perlu dipertegas terkait adanya tuduhan sebagian orientalist yang menyatakan bahwa dalam Al-Qur'an terdapat kisah yang tidak sesuai dengan fakta sejarah. Mereka bahkan menilai bahwa Al-Qur'an adalah karangan Muhammad, bukan turun dari Allah. ${ }^{11}$ Para penginjil hingga saat ini, termasuk di Indonesia masih berpegang pada pandangan subyektif terhadap ayat-ayat Al-Qur'an. Pandangan-pandangan miring mereka dapat dilihat, misalnya dalam website Isa dan Islam, ceramah agama di Youtube, dan dalam debat, terutama debat antara Islam dan

${ }^{9}$ Ilham Badu, Berita Terorisme Dalam Perspektif Media Cetak; Studi Kaus Koran Republika dan Koran Kompas, h.17.

${ }^{10}$ Lihat Fauzi Damrah, "Ifk" h. Dalam Sahabuddin et al (ed.), Ensiklopedia Al-Qur'an, Vol. 1, h. 342.

${ }^{11}$ Nashruddin Baidan, Wawasan Baru Ilmu Tafsir (Yogyakarta: Pustaka Pe;ajar, 2005), hH. 224. 
Kristen. Salah satu contoh yang mereka tunjukkan sebagai bukti bahwa dalam AlQur'an terdapat informasi yang tidak sesuai dengan realitas sejarah yaitu figur Harun dalam kisah Maryam. Mereka menilai ini sebagai suatu kesalahan besar karena terdapat jarak yang sangat jauh antara waktu hidupnya Nabi Harun as. yang mendampingi Nabi Musa as. dalam aktivitas dakwahnya dengan waktu hidup Maryam.

Pandangan tersebut menunjukkan betapa sempitnya wawasan pemahaman mereka terdapat ayat-ayat Al-Qur'an. Figur Harun dalam kisah Nabi Musa as. adalah figur realitas sedangkan figur Harun dalam kisah Maryam adalah makna kiasan (majâzî) yang mengacu pada keluarga yang saleh. Pada zaman Maryam orang baikbaik dinisbatkan kepada nama Harun, jadi bukan figur Harun secara personal dalam makna hakiki. Penyebutan seperti ini juga ditemukan dalam peradaban lain termasuk Indonesia.

Sebagai fakta sejarah, kisah-kisah dalam Al-Qur'an sebagian di antaranya sudah terbukti kebenarannya berdasarkan hasil penyelidikan ilmiah, dan masih banyak lagi yang belum ditemukan. Hal ini disebabkan keterbatasan pengetahuan dan ketrampilan manusia, namun suatu saat pasti akan ditemukan sejalan dengan semakin canggihnya ilmu pengetahuan dan teknologi. Di antara yang sudah ditemukan adalah jasad Fir'aun yang kini tersimpan di Musium Kairo, Mesir. Berita tentang jasad Fir'aun ini disebutkan dalam QS. Yunus (10): 92, "Maka pada hari ini Kami selamatkan badanmu supaya kamu dapat menjadi pelajaran bagi orang-orang yang datang sesudahmu dan Sesungguhnya kebanyakan dari manusia lengah dari tanda-tanda kekuasaan kami." Menurut catatan sejarah, setelah Fir'aun itu tenggelam mayatnya terdampar di pantai diketemukan oleh orang-orang Mesir lalu dibalsem, sehingga utuh sampai sekarang dan dapat dilihat di Musium Kairo, Mesir. Dalam peneltiannya Maurice Bucaille menemukan sisa garam yang menempel di tubuh Fir'aun menjadi bukti yang jelas bahwa mummi di Musum Cairo Mesir adalah betul Fir'aun. Kebenaran ilmiah yang terkandung dalam QS. Yunus (10): 92, menginsfirasi Maurice Bucaille masuk Islam. ${ }^{12}$

Dari Al-Qur'an juga diperoleh informasi tentang umat Nabi Shaleh as yaitu Kaum Tsamud. Kaum Tsamud atau disebut juga Ashab al-Hijr, penduduk batu, sebagai bangsa yang ahli dalam memahat gunung batu. Mereka ini hidup pada abd ke-8 SM. Dalam QS. al-A'raf (7): 74, Allah swt. berfirman: "Dan ingatlah olehmu di waktu Tuhan menjadikam kamu pengganti-pengganti (yang berkuasa) sesudah kaum 'Aad dan memberikan tempat bagimu di bumi. kamu dirikan istana-istana di tanahtanahnya yang datar dan kamu pahat gunung-gunungnya untuk dijadikan rumah; Maka ingatlah nikmat-nikmat Allah dan janganlah kamu merajalela di muka bumi membuat kerusakan."

Bukti-bukti historis peninggalan Kaum Tsamud ini telah ditemukan para ahli. Madain Shaleh, sekitar $470 \mathrm{~km}$ dari Madinah, Arab Saudi diklaim sebagai tempat tinggal Kaum Tsamud, umat Nabi Shaleh as. yang dimusnahkan oleh Allah swt. karena keingkarannya. Brian Doe, arkeolog, dalam bukunya "Southern Arabia, Thames and Hudson" menyebutkan bahwa Kaum Tsamud dikenali melalui tulisan dan pahatan yang mereka buat di dinding-dinding batu. Secara grafis tulisan itu

12 "Islam Perspektif: The Story of Maurice Bucaille's Inspiring Conversion to Islam," www.arabnews.com/news/443500 (22 Februari 2017). 
sangat mirip dengan huruf-huruf Smitic (Thalmudic) yang banyak ditemukan di Arabia Selatan sampai Hijâz. ${ }^{13}$

Batu-batu besar dengan ragam bentuk estetis berdiri kokoh di sepanjang jalan di Madain Shaleh. Lokasinya berpasir dengan gunung berbatu, batu-batu super besar berdiri tegak memisah dan sebagian menyatu berbentuk bukit. Di setiap sudut batunya, terdapat tekstur dengan beragam bentuk. Juga terdapat goresan garis-garis dalam bidang, menghadirkan volume cekung, cembung dan datar. Di situs bersejarah ini disebutkan memiliki 132 kamar dan kuburan.

\section{Berita Kandungan Ilmiah Al-Qur'an}

Kandungan ilmiah Al-Qur'an dibahas secara khusus dalam kajian tafsîr alilmî dan I'jâz al- 'ilmÎ. Pembahasan mengenai kandungan ilmiah ayat-ayat Al-Qur'an menjadi kajian debatable dan kontroversil. Kajian ini telah menempatkan sebagian pengkaji dalam posisi yang membingungkan. Di satu sisi secara teroretis ditolak oleh kalangan tertentu, tapi di sisi lain mereka juga menerapkan dalam karya tafsir mereka. Kondisi ini misalnya menempatkan Syekh Muhammad Abduh dan Muhammad Rasyid Ridha dalam posisi dilematis. Secara teoretis Abduh dan Ridha menolak I'jâz al-'ilmÍ, akan tetapi dalam tataran praktis mereka juga terjebak pada penggunaan tafsir ilmi. Dalam Tafsîr al-Manâr, keduanya menggunakan hasil-hasil temuan ilmu pengetahuan untu memahami ayat-ayat Al-Qur'an yang ditafsirkan. Kandungan ilmiah Al-Qur'an didukung oleh sebagian ahli dan ditolak oleh sebagian lainnya.

Kajian muatan ilmiah Al-Qur'an saat ini mendapatkan momentumnya. Ia memberi kontribusi besar dalam debat keagamaan khususnya antara Muslim dan Non-Muslim. Baik debatnya dilakukan di gedung maupun maupun di Taman Speakers' Corner, London atau kota-kota lain di Amerika dan Canada. Dalam beberapa tahun terakhir penemuan-penemuan ilmu pengetahuan modern menjadi alat ampuh dalam mempertahankan kebenaran agama Islam, khususnya Al-Qur'an. Kalau dulunya kebenaran Al-Qur'an sebagai Firman Tuhan dengan mudah dibantah dan ditolak oleh para penginjil karena hanya menggunakan ayat-ayat Al-Qur'an sebagai dalil. Saat ini para pendebat dari kalangan Kristen terlihat kesulitan dalam menanggapi pandangan pendebat Islam yang menggunakan temuan-temuan ilmu pengetahuan terhadap ayat-ayat Al-Qur'an. Apalagi temuan-temuan dimaksud dihasilkan oleh ilmuan Barat non-Muslim. Dr. Zakir Naik, pendebat Muslim, misalnya dengan lantang dan penuh percaya diri menegaskan di hadapan peserta debat yang berjumlah lebih 10.000 orang bahwa kalau semua kitab suci diuji dalam kasus kandungan ilmiah maka hanya Al-Qur'an yang lolos.

Dua contoh berita Al-Qur'an tentang kandungan ilmiah. Pertama, tujuh lapis langit dan tujuh lapis bumi. Dalam QS. al-Baqarah (2): 29, "Dia-lah Allah, yang menjadikan segala yang ada di bumi untuk kamu dan Dia berkehendak (menciptakan) langit, lalu dijadikan-Nya tujuh langit. Dan Dia Maha mengetahui segala sesuatu." Sepanjang perjalanan tafsir diperoleh berbagai penafsiran tentang tujuh lapis langit. 
Tujuh lapis langit di sini pernah ditafsirkan oleh salah seorang dengan tujuh planet. Di saat penafsiran dilakukan planet yang terdetesi memang baru tujuh buah. Dengan perkembangan selanjutnya di saat Astronomi dengan berbagai instrumentnya semakin canggih ditemukan planet lain. Dengan sendirinya penafsiran tujuh lapis langut dengan tujuh planet tidak bisa lagi diperpegangi.

Penafsiran mutakhir adalah tujuh lapis atmosfir yang mengelilingi bumi. Penafsiran ini didasarkan pada temuan mutakhir bahwa terdapat tujuh lapisan atmosfir yang mengelilingi bumi. Menurut Limited Fine Mesh Model (suatu model analisis atmosfir) digunakan untuk memperkirakan kondisi cuaca selama 48 jam, atmosfir itu sendiri terdiri atas tujuh lapis. Menurut definisi Geologi modern tujuh lapis atmosfir sebagai berikut: 1. Troposphere, 2. Stratosphere, 3. Mesosphere, 4. Thermosphere, 5. Exosphere, 7. Ionosphere, dan 7. Magnetosphere. Setiap lapis langit ini memiliki tugas masing-masing, sebagaimana disebutkan dalam QS. Fushshilat (41): 12, "Maka Dia menjadikannya tujuh langit dalam dua masa dan Dia menetapkan setiap langit fungsinya."

Sebagaimana langit bumi juga terdiri atas tujuh lapis. Thalaq (65): 12, Allah swt. berfirman: "Allah-lah yang menciptakan tujuh lapis langit dan seperti itu pula bumi." Berdasarkan sumber ilmiah terpercaya bumi memiliki tujuh strata. Ketujuh lapisan bumi yang diidentifikasi para ilmuan adalah sebagai berikut: 1. Lapisan pertama, lithosphere (air), 2. Lapisan kedua, lithosphere (darat), 3. Lapisan ketiga, asthenosphere, 4. Lapisan keempat, upper matle, 5. Lapisan kelima, inner mantle, 6. Lapisan keenam, outercom, 7. Lapisan ketujuh, innercom. ${ }^{14}$

Contoh kedua adalah campuran sperma. Dalam QS. al-Insan (72): 2-4, Allah berfirman: "Sesungguhnya Kami telah menciptakan manusia dari setetes mani yang bercampur yang Kami hendak mengujinya dengan perintah dan larangan . . ." Apa yang dimaksud dengan "air yang bercampur? Para mufassir termasuk Muhammad Asad, M. Quraish Shihab dan tim penerjemah Kementerian Agama RI. menafsirkannya dengan benih laki-laki bercampur dengan benih perempuan. Penelitian terbaru menunjukkan bahwa tanpa proses percampuran antara sperma dan ovum, sperma ini sendiri sudah merupakan campuran. Cairan yang disebut mani sesungguhnya tidak hanya mengandung sperma saja, tetapi sebaliknya ia tersusun dari campuran berbagai cairan yang berlainan. Cairan seminal merupakan suatu koleksi zat-zat yang keluar dari testis melalui gelembung seminal, kelenjar prostat dan kelenjar-kelenjar yang berhubungan dengan saluran air seni.

Suatu analisis detail mengenai cairan menunjukka bahwa ia terdiri atas banyak sekali zat yang terpisah. Dr. Elist secara garis besar menyebutkan tiga komposisi utama sperma, yaitu: 1. Protein, 2. Pructose, dan 3. Catecholamines. ${ }^{15}$ Ananya Mandal, dalam What is Sperm? Menyebutkan secara detail komposisi sperma ke dalam 20an zat, antara lain: Fructose, ascorbic acid, zinc, cholesterol, protein, calcium, chlorine, blood group antigens, citric acid, DNA, Magnesium, vitamin B12, phosphorus, sodium, potassium, uric acid, lactic acid, nitrogen, dan nutrisi-nutrisi

14 "The Layers of the Earth," http://www.miraclesofthequran.com/scientific 23.html (24 Juli 2011).

${ }^{15}$ Elist, What is Semen? http://www.newhealthguide.org/What-Is-In-Semen.html (23 Februari 2017) 
lain. ${ }^{16}$ Cairan-cairan ini masing-masing mempunyai fungsi yang diperlukan untuk menyediakan energi bagi sperma, menetralkan asam di pintu masuk Rahim, dan melicinkan lingkungan agar memudahkan proses perjalanan sperma. ${ }^{17}$

\section{Berita-berita Ghaib}

Berita ghaib dalam Al-Qur'an selalu menarik dan menantang. Dalam tulisan ini berita ghaib akan dilihat dari dua bagian. Pertama, terkait dengan entitas dan tempat. Entitas mencakup: malaikat, dan jin, sedangkan tempat meliputi: lawh mahfudh, arsy, sidratul muntaha dan alam mustawa'. Kedua, berita terkait dengan hari kiamat. Termasuk dalam hal ini adalah bagimana keadaan menjelang datangnya kiamat, keadaan sewaktu terjadi kiamat dan keadaan di syurga dan di neraka. Adapun tempat, properti, dan pertugas terkait dengan kehidupan ukhrawi atau eskatologis adalah: padang mahsyar, timbangan amal, syurga dan neraka, serta malaikat penjaganya. Informasi seputar kehidupan pada hari kemudian sepenuhnya diperoleh dari ayat-ayat Al-Qur'an dan Hadits Nabi. Tafsiran realitas (haqîq terhadap ayat-ayat yang menyebutkan hari kemudin akan dijumpai setelah terjadi kiamat. Gambaran tentang kehidupan setelah mati kan dilihat dan dirasakan secara langsung pada hari kiamat, setelah orang-orang bangkikt dari kubur masing-masing.

\section{Nabi Muhammad SAW Sebagai Pembawa Berita}

Salah satu fungsi utama seorang Rasul dalam Al-Qur'an adalah pembawa berita. Selain membawa berita gembira beliau juga memberi peringatan (QS. al-Ahzab (33): 45). Peran sebagai pembawa berita gembira dan peringatan ini sejatinya tercermin dalam tugas pemberitaan seorang wartawan. Dengan demikian aktivitas jurnalistik yang diemban bermuatan dakwah. Berita gembira dan peringatan terkait langsung dengan perbuatan manusia. Jika mereka melakukan pebuatan baik maka disiapkan pahala dan balasan yang menggembirakan pada hari kemudian. Sebaliknya, kalau mereka melakukan perbuatan jelek akan berdampak pada ganjaran yang menyakitkan pada hari kemudian. Selain menyampaikan berita dari Tuhan beliau juga menyampaikan berita hasil interaksi beliau dengan Jibril, para sahabat, bahkan dengan lingkungan sekitar. Berita-berita seperti ini tertuang dalam hadits-hadits beliau yang diriwayatkan secara mutawatir yang dapat dilihat sampai sekarang karena telah terkodifikasi dalam kitab-kitab hadits, khususnya, kitab hadits enam (al-kutub al-sittah). Enam Kitab hadis dimaksud adalah: 1. Shahịị Bukhârî, 2. Shahịị Muslim, 3. Sunan Abu Dawud, 4. Sunan al-Tirmidzî, 5. Sunan al-Nasâ'î, dan 6. Sunan Ibnu Majah.

Selain Nabi Muhammad saw. para sahabat nabi juga berperan sebagai penyebar berita. Dengan keterlibatan para sahabat ini berita-berita dari nabi dengan cepat menyebar ke masyarakat. Para sahabat ini di samping berperan sebagai penyampai berita dari nabi tetapi mereka juga menyampaikan berita-berita yang berasal dari masyarakat terkait dengan resepsi dan aplikasi ajaran Islam yang disampaikan kepada mereka. Para sahabat

\footnotetext{
${ }^{16}$ Ananya Mandal, "What is Semen?, http://www.news-medical.net/health/What-is-Semen.aspx 2017)

17 Sharif Kaf al-Ghazal, “Embryology and Human Creation between Qur'an and Science," http://www.islamicmedicine.org/embryoengtext.htm (22 Februari 2017).
}

(23 Februari 
ini sangat antusias dalam penyampaian berita ini, sampai ke tempat-tempat yang jauh bahkan desa terpencil.

\section{Media Sosial dan Fungsinya dalam Sistem Informasi di Indonesia}

Media sosial antara lain meliputi: facebook, twitter, instagram, youtube, dan blog. Fitur-fitur ini cenderung semakin banyak digunakan orang karena memudahkan dalam komunikasi. Melalui fitur-fitur ini pengguna akan dengan mudah berbagi ilmu, pengalaman dan ketrampilan. Selain itu fitur-fitur ini juga menjadi diskusi dan perdebatan dalam berbagai isu, khususnya dalam masalah agama. Di samping itu fiturfitur ini juga melatih kemampuan kritis seseorang dalam menanggapi sebuah postingan dan dalam menjawab pertanyaan yang diajukan pengguna lain. Sebagai tambahan, media ini juga menjadi ajang penyampain masalah, keluhan dan unek-unek seseorang dengan harapan akan ada pengguna lain memberikan jalan keluar dari masalah yang dihadapi.

Sebagai media, media sosial ini tentu penggunaannya sesuai kehendak yang menggunakan, bisa positif dan juga bisa negatif. Media sosial memiliki manfaat sekaligus mudarat bagi para penggunanya. Kegunaan positif antara lain: memposting artikel, menjual produk secara online, menjawab pertanyaan tertentu terkait masalah kesehatan, ekonomi, politik dan social budaya. Sementara kasus-kasus negatif dapat disebutkan antara lain: digunakan untuk menyampaikan ujaran kebencian (hater speech), membully seseorang, memprovokasi dan membuat atau menyebarkan berita bohong (hoax).

Media sosial memainkan peran penting dalam kehidupan. Berbagai fungsi telah diemban media sosial ini sehingga menjadi daya tarik tersendiri bagi khalayak. Beberapa fungsi media sosial di Indonesia dapat dikemukakan sebagai berikut:

\section{Sebagai media pertemanan dan silaturrahmi}

Pertemanan termasuk suatu kebutuhan dalam kehidupan. Banyaknya teman bisa menjadi indikator keluesan seseorang dalam bergaul dan berinteraksi di dunia maya. Mencari teman, memelihara pertemanan dan menambah jumlah teman dapat dicapai melalui media sosial dengan aneka fiturnya. Pemeliharaan pertemanan antara lain dilakukan dengan rajin memberi like komentar atas postingan teman, tentunya yang berkualitas. Salah satu hasil penelitian Totok Wahyudi Abadai dkk, mengenai penggunaan media soSial pada remaja di Sidorjo adalah media sosial memperkuat hubungan antara sesama pengguna situs. ${ }^{18}$ Pertemanan di media sosial ini skalanya lebih luas tidak dibatasi oleh sekat-sekat geografis, etnis, bahasa dan agama.

Media sosial juga memainkan peran pentingnya sebagai ajang silaturahmi. Menurut Hj L Weny Ramdiastuti, Pemimpin Redaksi Tribun Sumsel. dari hasil survei, pengguna sosial media usia di atas 50 tahun banyak menggunakan Facebook, tujuannya untuk bertemu dengan keluarga dan teman. Dengan demikian media sosial memang berfungsi sebagai media silaturrahmi. ${ }^{19}$

Menurut S.S. Budihardjo, Ketua Umum Forum Pimpinan Media Digital, lembaga yang dipimpinnya telah mewujudkan secara posistif peran media sosial sebagai ajang silaturrahmi. Berawal dari komunikasi melalui media social Facebook,

\footnotetext{
${ }^{18}$ Totok Wahyudi Abadi, Fandrian Sukmawan dan Dian Asha Utari, "Media Sosial dan Pengembangan Hubungan Interpersonal Remaja di Sidorjo," https://www.scribd.com/doc/216488304/MEDIA-SOSIAL-DANPENGEMBANGAN-HUBUNGAN-INTERPERSONAL-REMAJA-DI-SIDOARJO (23 Februari 2017)

${ }^{19}$ http://sumsel.tribunnews.com/2016/12/20/sosial-media-sebagai-sarana-silaturahmi-bukan-clbk Februari 2017)
} 
para pengelola media online membangun komunikasi yang dilatarbelakangi semangat kebersamaan tanpa sekat hingga kesepakatan menyatukan visi. ${ }^{20}$

\section{Sebagai media dan ajang bisnis}

Salah satu perkembangan dalam dunia bisnis adalah berbisnis lewat media sosial. Varian produk kebutuhan dan jasa layanan untuk masyarakat saat ini sudah ditawarkan melalui media sosial. Menurut Ali Kingston, Media sosial membantu bisnis dengan berbagai cara. Dengan media social pebisnis dapat menjangkau pelanggan dengan gratis, biayanya hanya energy dan waktu. Media ini dapat menurunkan biaya pemasaran pada level yang signifikan. ${ }^{21}$ Media social meningkatkan penjualan dan hasrat membeli pelanggan melalui interaksi secara regular dan pelayanan tepat waktu bagi pelanggan. Pada 2015 riset praktis terhadap penjualan terbaik dari riset institute MHI global, perusahaan kelas dunia menempatkan media social senagai cara yang paling efektif untuk mengidentififkasi pembuat keputusan dan peluang bisnis. Terkait dengan keadaan penjualan melalui media social 2015 , tercatat hamper $75 \%$ perusahaan terlibat dalam bisnis melalui media social melaporkan adanya peningkatan dalam penjualan dalam rentang waktu 12 bulan. $^{22}$

Melalui monitoring terhadap media social seseorang dapat mendapatkan informasi mengenai para pesaingnya. Kegiatan inteligen ini memungkinkan dia membuat keputusan strategis bisnis agar tetap berada di baris depan. Dengan kerja inteligen ini ia dapat mengawasi kata-kata kunci industri dan menyebutkan namanama pesaing dan produk-produknya. Berdasarkan hasil riset ini ia dapat memperbaiki bisnisnya dengan menawarkan penguatan-penguatan produk, pelayanan dan hal-hal lain yang tidak dimiliki pesaing.

\section{Sebagai media sharing ide dan karya ilmiah}

Membuka peluang bagi para penulis artikel dan blogger untuk menshare dan mendiseminasi berbagi artikel mereka. Audience akan menshare artikel seseorang kepada kelompoknya sehingga dapat memperkuat jaringan follower. Pemikiran dan gagasan cemerlang akan dengan mudah tersebar apalagi kalau ditulis dalam Bahasa Inggris. Para penulis bonafid akan mendapatkan tawaran untuk menulis artikel untuk jurnal tertentu baik nasional maupun internasional. Penggunaan media social dapat memperkokoh keterlibatan dan komunikasi kita dengan public dan agen-agen stakeholders yang lain. Penggunaan media social ini merupakan suatu aspek kunci dari sebuah inisiatif. Media sosial membuat seseorang atau suatu lembaga mencapai khalayak yang lebih luas dan agar dapat terlibat lebih baik, memberi informasi dan mendidik publik dalam waktu yang tepat melalui banyak saluran. ${ }^{23}$

\section{Sebagai media penyampaian pesan-pesan dakwah}

Salah perkembangan media dakwah mutakhir adalah melalui media sosial. Media sosial menyiapkan aneka fasilitas yang dapat dijadikan media dakwah.

${ }^{20} \mathrm{http}$ ://indonews.id/berita/forum-pimpinan-media-digital-jadikan-media-sosial-ajang-silaturahmi/ Februari 2017)

${ }^{21}$ Ali Kingston, "Posistive and Negative Effects of Social Media in Society,"

https://www.linkedln.com/pulse/positive-negative-effects-social-media-ali-kingston (11 Februari 2017)

22 https://blog.hootsuite.com/social-media-for-business/ (21 Februari 2017)

${ }^{23}$ https://www.nrc.gov/public-involve/open/social-media.html 21 Februari 2017) 
Muhammad Shahir, seperti dikutip Iqmar Omar, para dai tidak seharusnya membatasi diri hanya pada satu media tertentu saja dalam penyampaian dakwah di selururh dunia. ${ }^{24}$ Dengan varian fungsi media social, pesan dakwah dapat disampaikan dengan lebih menarik dan interaktif. Dalam pandangan Masduki Baidlowi, Ketua Komisi Informasi dan Komunikasi MUI, dakwah melalui media social adalah jalan yang murah dan strategis menjadi medium penyampaian dakwah. ${ }^{25}$ Di mata Muhammad Shahir, seperti dikutip Iqmar Omar, para dai tidak seharusnya membatasi diri hanya pada satu media tertentu saja dalam penyampaian dakwah di selururh dunia. Dakwah yang sangat menarik misalnya lewat youtube karena media ini menampilkan kemampuan audio visualnya. Ceramah agama dengan aneka variannya dapat didownload dan diupload di Youtube. Selain ceramah, Youtube juga menyediakan dakwah dalam bentuk debat. Bentuk dakwah paling menarik karena melibatkan dua pihak dengan keyakinan yang berbeda. Di samping itu materi debatnya didasarkan tema-tema kontroversil, seperti: Apakah Yesus itu Tuhan? Apakah Bible itu Firman Tuhan?

\section{E. Impilkasi Konsep Berita dalam Al-Qur'an dalam Sistem Pemberitaan di Media Sosial}

Konsep berita yang ditawarkan Al-Qur'an sangat signifikan dan memberi kontribusi dalam system pemberitaan pada media massa, khususnya media sosial. Beberapa implikasi dari konsep berita dalam Al-Qur'an dalam system pemberitaan sebagai berikut:

\section{Sumber berita harus jelas}

Berita sangat penting dalam kehidupan. Ia bahkan telah menjadi salah satu kebutuhan sebagaimana kebutuhan lainnya, seperti makan dan minum. Masyarakat, khususnya di perkotaan agaknya tidak bisa dipisahkan dari berita. Sejak seseorang bangun dari tidur pertama-tama yang diburunya adalah berita. Demikian pula sebelum ke tempat tidur sebagian orang akan menyaksikan berita paling akhir dari media penyedia berita. Berita layaknya energy kehidupan, sehingga bagi orang-orang tertentu akan terlihat kurang semangat, tidak energik jika tidak mendapatkan berita-berita baru. Sumber-sumber berita telah menjadi mata air kehidupan yang senantiasa dilacak untuk mendapatkan berita yang segar dan lagi viral.

Sumber berita cukup banyak dan beragam. Karena itu diperlukan kemampuan selektivitas terhadap sumber-sumber berita. Hal ini bertujuan agar diperoleh berita yang betul-betul meyakinkan sebagai sebuah kebenaran, atau sesuai dengan fakta. Kualitas berita sangat ditentukan oleh kredibiltas sumbernya. Al-Qur'an mengisyaratkan perlunya memeriksa dengan cermat sumber berita. Dalam QS. al-Hujurat (49): 6 Allah swt. berfirman: "Hai orang-orang yang beriman, jika datang kepadamu orang Fasik membawa suatu berita, Maka periksalah dengan teliti agar kamu tidak menimpakan suatu musibah kepada suatu kaum tanpa mengetahui keadaannya yang menyebabkan kamu menyesal atas perbuatanmu itu.

\footnotetext{
${ }^{24}$ Faradilla Iqmar Omar, "Penerimaan Media Sosial sebagai Medium Dakwah dalam Kalangan Mahasiswa KUIS," www.kuis.edu.my/com2014/eproceedings/C007 PENERIMAAN-MEDIA-SOSIAL-SEBAGAI-MEDIUM DAKWAH (21 Februari 2017)
}

\footnotetext{
${ }^{25}$ News.Detik.com, “Ulama Upayakan Pakai Media Sosial sebagai Medium Dakwah,” https://news.detik.com/berita/d-3354863/ulama-upayakan-pakai-media-sosial-sebagai-medium-dakwah
} Februari 2017) 


\section{Berita harus benar}

Berita dari berbagai sumber membanjiri ruang baca khalayak. Varian berita ini jelas memerlukan kearifan untuk memilah dan memilih dari khalayak pembaca. Diperlukan kecermatan dan kejelian ekstra dalam memilah dan memilih berita yang akan dibaca. Apalagi kalau berita tersebut menyentuh hal-hal sensitif dalam kehidupan, misalkan terkait dengan isuisu SARA. Kebenaran berita menjadi pertimbangan utama, terlepas dari menarik atau tidaknya berita tersebut. Kebenaran menjadi fokus perhatian karena terkait dengan beberapa hal: 1 . Kemungkinan dampak yang ditimbulkan, 2. Komentar yang akan diberikan, dan 3. Pertimbangan untuk dishare ke teman di Facebook.

Kebenaran sebuah berita harus didasarkan pada kriteria tertentu. Salah satu kriteria yang patut dipertimbangkan adalah kebenaran agama karena ia berasal dari wahyu Tuhan Sang Pencipta alam semesta. ${ }^{26}$ Wahyu Tuhan ini telah terkodifikasikan dalam kitab suci. Kitab suci, karena ia berasal dari Tuhan maka ia memiliki kebenaran mutlak (QS. al-Baqarah (2): 213). Sebagai standar kebenaran, Al-Qur'an berfungsi sebagai tolok ukur (muhaymin) dan pengoreksi (mushaddiq) kitab-kitab suci lainnya (QS. al-Maidah (5): 48). Selain itu Al-Qur'an juga berfungsi sebagai landasan hukum dan peraturan atas kasus-kasus hukum yang dihadapi masyarakat (QS. al-Baqarah (2): 213). Sebagai tambahan, Al-Qur'an juga berfungsi sebagai peringatan dan pelajaran bagi manusia, khususnya orang-orang beriman. Pemahaman akan sebuah makna ayat juga harus didasarkan kredibilitas dan kompetensi penafsirnya. Kedua, berasal dari Rasul atau utusan Tuhan. Sebagai utusan Tuhan dipastikan para rasul menyampaikan kebenaran dari Tuhan. Mereka itu mendapatkan jaminan Tuhan akan kebenaran pesan-pesan yang disampaikan kepada umat. Rasulullah saw. misalnya sejak masih muda sudah mendapatkan gelar terpercaya "al-Amîn" dari komunitas Arab. Beliau dipercaya untuk memimpin para kepala suku untuk memindahkan Hajratul Aswad ke tempatnya semula setelah bergeser karena banjir.

Selain itu secara skriptural Rasulullah saw. mendapatkan justifikasi Ilahi atas kebenaran dan kejujurannya yang memang layak mengemban tugas pewahyuan. Dalam QS. Allah berfirman: "Dan tidak Muhammad itu berbicara mengikuti hawa nafsunya, melainkan berdasarkan wahyu di sampaikan kepadanya." Dengan demikian Allah memerintahkan untu mengambil atau menerima apa yang dibawa oleh Rasul. Dalam QS. Allah berfirman: "Dan apa yang dibawa Rasul kepadamu terimalah dan apa yang dilarangnya jauhilah." Lebih dari itu Nabi Muhammad saw. mendapatkan legitimasi dari Tuhan sebagai insan yang memiliki integritas yang tinggi. Dalam QS. al-Qalam (68): 4, Allah swt. berfirman: "dan Sesungguhnya kamu benarbenar berbudi pekerti yang agung".

\section{Berita harus sesuai dengan fakta}

Realitas faktual atau realitas historis menjadi syarat bagi sebuah berita. Berita dari Tuhan dipastikan memiliki realitas faktual. Dalam QS. al-An'am (6): 67, Allah berfiran: "untuk Setiap berita (yang dibawa oleh rasul-rasul) ada (waktu) terjadinya dan kelak kamu akan mengetahui." Karena itu menjadi tantangan bagi manusia untuk meneliti dengan berbagai kapasitas yang dimiliki untuk mencari bukti-bukti historis dari sebuah berita dalam Al-Qur'an. Demikian pula menjadi tantangan bagi mereka untuk menggali nilai-nilai ilmiah Al-Qur'an melalui penelitian yang tdak kenal lelah. Alam semesta menjadi ajang penelitian yang tidak pernah final dan

\footnotetext{
${ }^{26}$ Menurut Amsal Bakhtiar, sebagaimana dikutip Nurudin, ada beberapa teori kebenaran, antara lain: 1. Teori kebenaran korespondensi, 2. Teori kebenaran koherensi, 3. Teori kebenaran pragmatis, 4. Teori kebenaran sintaksis, 5. Teori kebenaran semantic, 6. Teori kebenaran nondeskripsi, dan 7. Teori kebenaran Agama. Penjelasan teori-teori kebenaran ini dapat dilihat dalam Nuruddin, Jurnalisme Masa Kini (Jakarta: Rajawali Press, 2009$),$ h. 117-134.
} 
senantiasa menantang. Thanthawi Jawhari menyebutkan terdapat sekitar 750 ayat tentang alam semesta, yang tentunya menantang untuk diteliti.

Salah satu trend yang menandai bagian akhir tahun 2016 adalah begitu banyaknya beredar berita bohong atau hoax. Berita seperti ini dipastikan mengada-ada atau tidak sesuai dengan realitas di masyarakat. Berita hoax ini dibuat untuk tujuan tertentu dan biasanya marak di kala masyarakat menghadapi suksesi kepemimpinan politik. Jenis berita ini sungguh merugikan fihak-fihak tertentu karena mereka mempercayainya dan langsung mengamalkannya. Pada paruh 2016, pernah ada berita di salah satu Koran menyebutkan bahwa kembang "dollar" sangat berbahaya dapat menyebabkan penyakit yang mematikan. Banyak yang mempercayainya dan segera memusnahkan atau membuang kembang tersebut yang sudah dipelihara sekian lama. Setelah penulis mengeceknya di internet ternyata berita tadi hoax.

QS. al-Hujurat (49): 6 yang telah disebutkan di atas mengisyaratkan perlunya crosscheck atau check and recheck atas berita yang dibaca. Saat ini crosscheck akan mudah dilakukan karena banyak penyedia berita yang tersedia. Crosschek sangat penting bagi penyedia berita dengan melacak sumber-sumber berita yang kredibel sebelum memberitakan atau mempostingnya. Selain penyedia berita khalayak juga harus semakin cerdas dalam mengakses sebuah berita, diperluakn daya kritis terhadap berita yang dibaca. Tidak boleh langsung meyakini kebenaran berita yang diterima. Mereka juga harus melakukan crosscheck atau check and recheck terhadap berita yang dihadapi untuk mengetahui apakah ia sesuai dengan fakta atau tidak.

\section{Kesimpulan}

Berita sesuai levelnya dapat menimbulkan kegoncangan dalam tatanan kehidupan masyarakat. Karena itu diperlukan pedoman dan bimbingan khsusus dalam berinteraksi dengan berita. Al-Qur'an sebagai kitab suci universal dipastikan memiliki panduan bagi mereka yang bekerja dalam lembaga pemberitaan. Demikian pula terhadap warga masyarakat yang setiap saat diterpa dengan aneka berita dari berbagai penjuru dunia. Al-Qur'an berisi konsep-konsep berita yang sekayaknya digali dan diterapkan dalam system pemberitaan, khususnya bagi media sosial. Panduan memang sangat diperlukan mengingat media social itu netral tergantung para penggunanya apakah akan digunakan untuk hal-hal positif atau negatif. Media sosial memiliki manfaat yang sangat banyak, di samping tentunya mengandung mudarat. Dengan bimbingan AlQur'an diharapkan umat Islam akan lebih memanfaatkan media sosial untuk tujuan positif dan menghindari pemanfaatan media sosial untuk tujuan negatif

\section{DAFTAR PUSTAKA}

\section{A. Referensi Cetak}

Badu, Ilham. Berita Terorisme Dalam Perspektif Media Cetak; Studi Kasus Koran

Republika dan Koran Kompas, h.16-17.

Baidan, Nashruddin. Wawasan Baru Ilmu Tafsir.Y ogyakarta: Pustaka Pelajar, 2005.

Damrah, Fauzi "Ifk” dalam Sahabuddin et al (ed.), Ensiklopedia Al-Qur'an: Kajian

Kosakata, Vol. I. Jakarta: Lentera Hati, 2007.

Hidayat, Komaruddin. Memahami Bahasa Agama: Sebuah Kajian Hermenutik.

Jakarta: Paramadina, 1996.

Mattola, M. Galib. "naba" dalam Sahabuddin et al (ed.). Ensiklopedia Al-Qur'an:

Kajian Kosakata, Vol. 2. Jakarta: Lentera Hati, 2007. 
Nuruddin, Jurnalisme Masa Kini. Jakarta: Rajawali Press, 2009.

Shihab, M. Quraish. Tafsir Al-Mishbah:Pesan, Kesan dan Keserasian Al-Qur'an, Vol 15. Jakarta: Lentera Hati, 2002.

Zakariyya, Abu Al-Husain Ahmad ibn Faris ibn. Mu'jam Maqayis fi al-Lughah. Cet. I; Beirut: Dar al-Fikr, 1994.

Damrah, Fauzi “Ifk” dalam Sahabuddin et al (ed.), Ensiklopedia Al-Qur'an: Kajian Kosakata, Vol. I. Jakarta: Lentera Hati, 2007.

\section{B. Referensi Online}

Ali Kingston, "Posistive and Negative Effects of Social Media in Society," https://www.linkedIn.com/pulse/positive-negative-effects-social-media-ali-kingston (11 Februari 2017) https://hshidayat.wordpress.com/2013/12/11/tabayyun-terhadap-informasi-bagian-terpentingtanggungjawab-media-islam/ (09 Februari 2017) http://news.liputan6.com/read/2621897/melongok-jejak-kaum-tsamud-umat-nabi-saleh-dimadain-saleh?ref=yfp $\quad$ (08 Oktober 2016)

https://www.nrc.gov/public-involve/open/social-media.html 21 Februari 2017)

Faradilla Iqmar Omar, "Penerimaan Media Sosial sebagai Medium Dakwah dalam Kalangan Mahasiswa KUIS," www.kuis.edu.my/com2014/eproceedings/C007_PENERIMAAN-MEDIA-SOSIAL-SEBAGAIMEDIUM DAKWAH (21 Februari 2017)

News.Detik.com, "Ulama Upayakan Pakai Media Sosial sebagai Medium Dakwah," https://news.detik.com/berita/d-3354863/ulama-upayakan-pakai-media-sosial-sebagai-mediumdakwah (21 Februari 2017)

https://blog.hootsuite.com/social-media-for-business/ (21 Februari 2017)

"Islam Perspektif: The Story of Maurice Bucaille's Inspiring Conversion to Islam," www.arabnews.com/news/443500 (22 Februari 2017).

Sharif Kaf al-Ghazal, "Embryology and Human Creation between Qur' an and Science," http://www.islamicmedicine.org/embryoengtext.htm (22 Februari 2017).

Totok Wahyudi Abadi, Fandrian Sukmawan dan Dian Asha Utari, "Media Sosial dan Pengembangan Hubungan Interpersonal Remaja di Sidorjo," https://www.scribd.com/doc/216488304/MEDIA-SOSIAL-DAN-PENGEMBANGANHUBUNGAN-INTERPERSONAL-REMAJA-DI-SIDOARJO (23 Februari 2017)

http://sumsel.tribunnews.com/2016/12/20/sosial-media-sebagai-sarana-silaturahmibukan-clbk (23 Februari 2017)

http://sumsel.tribunnews.com/2016/12/20/sosial-media-sebagai-sarana-silaturahmibukan-clbk (23 Februari 2017)

http://indonews.id/berita/forum-pimpinan-media-digital-jadikan-media-sosial-ajangsilaturahmi/ (23 Februari 2017)

Elist, What is Semen? http://www.newhealthguide.org/What-Is-In-Semen.html

Februari 2017)

Ananya Mandal, "What is Semen?, http://www.news-medical.net/health/What-isSemen.aspx (23 Februari 2017) 